\title{
METRICS DEVELOPMENT FOR PATENTS
}

\author{
Desenvolvimento de métricas para patentes
}

Daniela Francescato Veiga ${ }^{1}$, Lydia Masako Ferreira ${ }^{2}$

\author{
A B STRACT
}

\begin{abstract}
Objective: To develop a proposal for metrics for patents to be applied in assessing the postgraduate programs of Medicine III - Capes. Methods: From the reading and analysis of the 2013 area documents of all the 48 areas of Capes, a proposal for metrics for patents was developed to be applied in Medicine III programs. Results: Except for the areas Biotechnology, Food Science, Biological Sciences III, Physical Education, Engineering I, III and IV and Interdisciplinary, most areas do not adopt a scoring system for patents. The proposal developed was based on the criteria of Biotechnology, with adaptations. In general, it will be valued, in ascending order, the deposit, the granting and licensing/production. It will also be assigned higher scores to patents registered abroad and whenever there is a participation of students. Conclusion: This proposal can be applied to the item Intellectual Production of the evaluation form, in subsection Technical Production/Patents. The percentage of $10 \%$ for academic programs and $40 \%$ for Masters Professionals should be maintained. The program will be scored as Very Good when it reaches 400 points or over; Good, between 200 and 399 points; Regular, between 71 and 199 points; Weak up to 70 points; Insufficient, no punctuation.
\end{abstract}

Key Words: Intellectual property. Patents. Classification. Licensure.

\section{INTRODUCTION}

$\Lambda$ patent is a temporary property title granted by the State, by law, which confers on the holder, or his successors, the right to prevent third parties, without consent, to produce, use, offer for sale, sell or import object of his patented product, 1,2

The agency responsible for granting patents in Brazil is the National Institute of Industrial Property (INPI), Ministry of Development, Industry and Foreign Trade. It was created by Law No. 5,648, of 11/12/1970, and regulated by Decree No. 68104 of 22/01/1971.

The granting of patents in Brazil is governed by Law No. 9,279, of 14/05/1996, known as the Industrial Property Law (IPL), which regulates the rights and obligations relating to industrial property, considering its social interest and technological development and economy of the country. Is this law that provides patents in Brazil1,3.

The patent is valid only in the countries where it was applied for granting protection. Each country is sovereign to grant or not the patent, regardless of the decision in other countries of patent applications (art. 4 of the "Convention of the Paris Union for Protection of Industrial Property") 1.2. $^{1.2}$

There are two ways to apply the protection invention in other countries. One is via the "Convention of the Paris Union for the Protection of Industrial Property" (CUP). The CUP was established in Paris in 1883, and Brazil figures among its first 14 signatories. In this case, the order is placed directly in the country where the protection is wanted ${ }^{1,4}$

The other alternative for deposit in other countries is to use the "Treaty of Cooperation on Patents" (PCT - Patent Cooperation Treaty). The filing of the application by means of this treaty is called "international patent application", and can be made in Brazil, in INPI receptions, in other treaty countries-member or directly in the international office in Genebra ${ }^{1,5}$

The LPI provides for two types of patent (LPI - article 2 section I): the patent and utility model. The patent applies to products or processes that meet the requirements of inventive step, novelty and industrial application, and is valid for 20 years from the filing date. The utility model refers to object of practical use, or part thereof, susceptible of industrial application, presents a new shape or arrangement and involves an inventive act that results in functional improvement in its use or manufacture. Is valid for 15 years from the filing date. It is important to note that cannot patent a process as a utility model, only as patent invention ${ }^{1-3}$.

An invention is patentable when it meets simultaneously the three basic requirements: novelty, inventive step and industrial application (Article 8 of the IPL). A utility model is patentable when the object of practical use meets the requirements of novelty in the new form or arrangement, industrial application and involves an inventive act that results in functional improvement in its use or in its manufacture (Art. 9 of LPI) $)^{1-3}$.

For a better understanding of the patentability requirements, the definition of what is required to be the "prior art". It consists of everything made available to the public before the filing date of the patent application, by written or oral description, by use or any other means, in Brazil or abroad (Article $11 \S 1$ of the IPL). The date that limit the state of the art in relation to the patent application is considered, in principle, as the date of the deposit. That is, if the public view is done before deposit by any means, written or oral, the idea lost novelty, basic requirement for getting patentability in both patent types ${ }^{1-3}$

The application goes through the following phases ${ }^{6}$ : 1. search for determination of state of the art;

2. preparation of the application form, technical report, claims, abstract and drawings;

3. protocol application;

4. preliminary examination by the INPI;

5. delivery of the patent application with the final numbering of the process;

6. depositary notification in the Journal of Industrial Property (applicant's name, date of filing and application number):

7. publication of the application filed with data, abstract and drawing (after 18 months):

8. request the inspection (up to 36 months after the deposit);

9. granting of the patent application:

10. payment and proof of return (within 60 days);

11. dispatch a patent letter (within 60 days).

The exclusive right arises only with the grant of the patent, formalized by the delivery of the document entitled Patent Letter. Only from the concession, holder can prevent others to enjoy the process/product, which is private, under civil and criminal penalties, in accordance with the privileges and limitations established by law.

Finally, ideally, the patent should lead to a license agreement. This is done with industry or company that will pay royalties to the patent holder to produce or use the patented product or process ${ }^{6}$

${ }^{1}$ Programa de Pós-Graduação em Cirurgia Translacional, Universidade Federal de São Paulo, São Paulo, SP, Brasil, e Mestrado Profissional em Ciências aplicadas à Saúde, Pouso Alegre, MG ('Postgraduate Program in Translational Surgery, Federal University of São Paulo, São Paulo, SP, Brazil, and Professional Master's in Applied Sciences for Health, Pouso Alegre, MG), Brazil

2Programa de Pós-Graduação em Cirurgia Translacional, Universidade Federal de São Paulo, São Paulo, SP, Brasil, Coordenadora da Área Medicina III da Capes, Brasília, DF ('Postgraduate Program in Translational Surgery, Federal University of São Paulo, São Paulo, SP; Area Coordinator Medicine III - CAPES, Brasília, DF), Brazil 
It is the licensing of patents that establishes technology transfer to the productive sector, allowing innovation, creating jobs and income ${ }^{7,8}$. However, in general, the licensing percentage is still very low in Brazil ${ }^{9}$.

Medicine III has no specific criteria for the evaluation of patents produced in their PPG, since the master's professionals are recent and still there was no assessment.

This study aimed to develop a metrics proposal for patents to be applied in the area.

\section{METHODS}

This study was designed and prepared for the $V$ National Graduate Meeting - Medicine III of CAPES, held on 8 and 9 December 2014, in São Paulo, Brazil, where he was introduced.

Initially was proceeded reading of all 2013 documents of 48 Capes areas. From the analysis of these documents, and considering the interest of Medicine III in stimulating its PPG to seek concession and licensing of patents at home and abroad preferably with the participation of students, a metrics proposal for patent was developed be used on PPG area evaluation.

This proposal may be included in PPG Medicine III item Intellectual Production, sub-item Technical Productions/ Patents. Should be applied to professional master's degrees and also to academic programs, observing, respectively, the percentages of $40 \%$ and $10 \%$ of the weight assigned to the item Intellectual Production in both modalities ${ }^{10}$.

\section{RESULTS}

Careful analysis of the 2013 area documents showed that most areas do not adopt specific metrics for valuing patents and, among those describing the assessment of patent system, largely proposes qualitative evaluation. Areas as Biotechnology, Food Science, Physical Education, Engineering I, III and IV and Interdisciplinary adopt a scoring system for patents; Biological Sciences III area uses the same criteria of Biotecnology $y^{11-18}$.

In general, it is valued in ascending order the deposit, the granting and licensing/production. Most areas do not differentiate licensing at home and abroad for the score, except for the areas of Food Science, Pharmacy and Chemistry, which assign higher scores to records abroad ${ }^{12,19,20}$. Most also does not mention more points in case of student participation.

A proposal for development of metrics for patents for Medicine III, based on Biotecnology ${ }^{11}$ criteria, with modifications was then drawn up. Figure 1 presents the scores suggested, according to the stage where the process is.

\begin{tabular}{|l|l|}
\hline Description & Score \\
\hline Patent deposit & 70 points \\
\hline Software or product registered in the competent agency & 70 points \\
\hline Patent filed in partnership with companies & 90 points \\
\hline Patent granted & 140 points \\
\hline Patent licensed & 200 points \\
\hline Licensed patent and producing (with proof) & 500 points \\
\hline
\end{tabular}

\section{FIGURE 1 - Proposal to patent score for Medicine III - Capes} namely:

To this score some caveats are applied in specific cases,

if the PPG have more than one licensed and producing patent in three years, only one will worth 500 points and the others 200 points each;

in case of students participation the score will be doubled, except for licensed and producing patent, that will accrue 200 points for the participation of students, totaling 700 points;

the score will also be doubled in case of foreign registry, except for licensed and producing patents, where will accrue 200 points for registration abroad, following the base score of each level (ie, if it has been doubled, the participation of students will accrue the points initially allocated, ie triplicate the initial value).

From this score, criteria for assessment of PPG Medicine III were elaborated (Figure 2).

\begin{tabular}{l|l}
$\begin{array}{ll}\text { Concept } \\
\text { Very Good }\end{array}$ & PPG score \\
Zood & 400 points / three years \\
\hline Regular & Between 200 and 399 points / three years \\
\hline $\begin{array}{l}\text { Weak } \\
\text { Deficient }\end{array}$ & To 70 points / three years \\
\hline
\end{tabular}

FIGURE 2 - Proposal for allocation of concepts according to the score of patents for Medicine III - Capes

The proposed metrics for patent may be applied to item 4 of the evaluation form of PPG Medicine III, with regard to Intellectual Production, and represents 35\% of the assessment. Within these $35 \%$, the sub-item on the Technical Production/ Patents keep the percentage of $10 \%$ for academic PPG and $40 \%$ for professional master's $s^{10}$.

\section{DISCUSSION}

The professional master degree is very new modality in Medicine III. The oldest course is the Federal University of the State of Rio de Janeiro - UNIRIO, which began in $2011^{10}$. In the last triennial review in 2013, this course was not completed a three-year period of operation and therefore was not evaluated.

That is, the Medicine III has not yet assessed professional masters degree, therefore, has no well-established parameters for the assessment of the technical production, essential in professional master. With the recent increase in the number of these masters recommended by Capes and evaluated by the Medicine III, the development of these parameters is fundamental.

Some areas welcome greater number of professional master's degrees, and therefore already have established metrics for different technical productions, including patents. The criteria of these areas, in particular those developed by the Biotechnology, guided the development of the proposal for Medicine III11-18

Whereas only the licensing of the patent leads to the generation of jobs, income and therefore economic and social country development ${ }^{7-9}$ it was proposed that the assessment would valorize in ascending order the deposit, grant and licensing/production. Also with a view to the international context of the area and the country, it was proposed, like the areas of Food Science, Pharmacy and Chemistry, higher valuation of patents registered and licensed abroad ${ }^{12,19,20}$. And considering the essential mission of postgraduate training of human resources, proposed to award more points for student participation.

The purpose of this metrics proposal for patent does not adhere exclusively to the numbers. All the proposition are relative, only to give parameters, and must be analyzed together with the metrics proposed for other technical productions.

\section{CONCLUSION}

The proposed metrics for patent presented here can be applied to the item Intellectual Production of the evaluation form of PPG Medicine III, in subsection Technical Productions, patents and other productions considered relevant should be maintained in this subsection, the percentage of $10 \%$ for PPG academics and $40 \%$ for professional master's degrees. Will be considered Very Good (MB) PPG that get 400 points/three years or more; Good (B) between 200 and 399 points; Regular (R) between 71 and 199 points; Weak (F) to 70 points; and Deficient (D) without scoring. 


\section{RESUMO}

Objetivo: Desenvolver uma proposta de métricas para patentes a serem aplicadas na avaliação dos Programas de Pós-Graduação da Área Medicina III - Capes. Métodos: A partir da leitura e análise dos documentos de área de 2013 de todas as 48 Áreas da Capes, desenvolveu-se uma proposta de métricas para patentes, a ser aplicada na avaliação dos programas da área. Resultados: Constatou-se que, com exceção das áreas Biotecnologia, Ciência de Alimentos, Ciências Biológicas III, Educação Física, Engenharias I, III e IV e Interdisciplinar, a maioria não adota sistema de pontuação para patentes. A proposta desenvolvida baseou-se nos critérios da Biotecnologia, com adaptações. De uma forma geral, foi valorizado, em ordem crescente, o depósito, a concessão e o licenciamento/ produção. Também foi atribuída maior pontuação a patentes registradas no exterior e com participação de discentes. Conclusão: Esta proposta poderá ser aplicada ao item Produção Intelectual da ficha de avaliação, no subitem Produções Técnicas, patentes e outras produções consideradas relevantes. Deverá ser mantida, neste subitem, a porcentagem de $10 \%$ para os programas acadêmicos e $40 \%$ para os mestrados profissionais. Será considerado Muito Bom o programa que obtiver 400 pontos/triênio ou mais, Bom entre 200 e 399 pontos; Regular entre 71 e 199 pontos; Fraco até 70 pontos; e Deficiente sem pontuação.

Descritores: Propriedade intelectual. Análise prévia de registro de produto. Patentes. Classificação. Licenciamento

\section{REFERENCES}

1. Portal INPI. Disponível em: http://www.inpi.gov.br/portal/acessoainformacao/artigo/patente_1351691647905. Acesso em 30/11/2014

2. Ministério do Desenvolvimento, Indústria e Comércio Exterior - Instituto Nacional de Propriedade Industrial - INPI. Guia de Depósitos de Patentes. 2008. Disponível em: http://www.inpi.gov.br/images/ stories/downloads/patentes/pdf/Guia_de_Deposito_de_Patentes. pdf. Acesso em 18/11/2014.

3. Presidência da República. Casa Civil. Subchefia para Assuntos Jurídicos. Lei n 9.279, de 14/05/1996. Disponível em: http://www. planalto.gov.br/ccivil_03/leis/l9279.htm. Acesso em 30/11/2014.

4. Instituto Nacional de Propriedade Industrial - INPI. Convenção de Paris. Disponível em: http://www.inpi.gov.br/images/stories/CUP. pdf. Acesso em 30/11/2014.

5. World Intellectual Property Organization - WIPO. Patent Cooperation Treaty. Disponível em: http://www.wipo.int/pct/en/texts/ articles/atoc.htm. Acesso em 30/11/2014.

6. Informe Federal. Fases do Pedido - Patente. Disponível em: http:// www.informefederal.com.br/artigos/patente/fases-do-pedido/. Acesso em 18/11/2014

7. Marques F. Muito além das patentes. Pesquisa Fapesp. 2012; 197: 20-27.

8. Ribeiro BS. Propriedade industrial: o contrato de licença compulsória de uso de patentes e seus sucedâneos. Disponível em: http://www.ambito-juridico.com.br/site/index.php?n_link=revista_artigos_leitura\&artigo_id=7792. Acesso em 30/11/2014.

9. American Chamber of Commerce for Brazil - AMCHAM Brasil. Produzir patentes é importante, mas só com licenciamento de tecnologias haverá mais empregos e renda. Disponível em: http:// www.amcham.com.br/inovacao/noticias/produzir-patentes-e-importante-mas-so-com-licenciamento-de-tecnologias-e-que-havera-mais-empregos-e-renda-5890.html. Acesso em 30/11/2014

10. Documento de área e Comissão da Trienal 2013. Área Medicina III. Disponível em: http://capes.gov.br/images/stories/download/avaliacaotrienal/Docs_de_area/Medicina_III_doc_area_e_ comiss\%C3\%A3o_att08deoutubro.pdf. Acesso em 18/11/2014.

11. Documento de área e Comissão da Trienal 2013. Área Biotecnologia. Disponível em: http://capes.gov.br/images/stories/ download/avaliacaotrienal/Docs_de_area/Biotecnologia_doc_ area_e_comiss\%C3\%A3o_block.pdf. Acesso em 18/11/2014.
12. Documento de área e Comissão da Trienal 2013. Área Ciência de Alimentos. Disponível em: http://capes.gov.br/images/stories/ download/avaliacaotrienal/Docs_de_area/Ci\%C3\%AAncia_de_Alimentos_doc_area_e_comiss\%C3\%A3o_21out.pdf. Acesso em $18 / 11 / 2014$

13. Documento de área e Comissão da Trienal 2013. Área Educação Física. Disponível em: http://capes.gov.br/images/stories/download/avaliacaotrienal/Docs_de_area/Educa \% C 3\% A7\% C 3\%A3o_F\% C 3\%ADsica_doc_area_e_ comiss\%C3\%A3o_att08deoutubro.pdf. Acesso em 18/11/2014.

14. Documento de área e Comissão da Trienal 2013. Área Engenharias I. Disponível em: http://capes.gov.br/images/stories/download/ avaliacaotrienal/Docs_de_area/Engenharias_I_doc_area_e_ comiss\%C3\%A3o_16out.pdf. Acesso em 18/11/2014.

15. Documento de área e Comissão da Trienal 2013. Área Engenharias III. Disponível em: http://capes.gov.br/images/stories/download/ avaliacaotrienal/Docs_de_area/Engenharias_III_doc_area_e_ comiss\%C3\%A30_16out.pdf. Acesso em 18/11/2014.

16. Documento de área e Comissão da Trienal 2013. Área Engenharias IV. Disponível em: http://capes.gov.br/images/stories/download/ avaliacaotrienal/Docs_de_area/Engenharias_IV_doc_area_e_ comiss\%C3\%A30_16out.pdf. Acesso em 18/11/2014.

17. Documento de área e Comissão da Trienal 2013. Área Interdisciplinar. Disponível em: http://capes.gov.br/images/stories/ download/avaliacaotrienal/Docs_de_area/Interdisciplinar_doc area_e_comiss\%C3\%A3o_block.pdf. Acesso em 18/11/2014.

18. Documento de área e Comissão da Trienal 2013. Área Ciências Biológicas III. Disponível em: http://capes.gov.br/images/stories/ download/avaliacaotrienal/Docs_de_area/Ciencias_Biologicas_III_doc_area_e_comiss\%C3\%A3o_block.pdf. Acesso em $18 / 11 / 2014$.

19. Documento de área e Comissão da Trienal 2013. Área Farmácia. Disponível em: http://capes.gov.br/images/stories/download/ avaliacaotrienal/Docs_de_area/Farm\%C3\%A1cia_doc_area_e_ comiss\%C3\%A3o_att08deoutubro.pdf. Acesso em 18/11/2014.

20. Documento de área e Comissão da Trienal 2013. Área Química. Disponível em: http://capes.gov.br/images/stories/ download/avaliacaotrienal/Docs de_area/Quimica_doc area_e comiss\%C3\%A3o_att08deoutubro.pdf. Acesso em 18/11/2014.

Received on: 19/02/2015

Accepted for publication: 12/09/2015

Conflict of interest: none

Source of funding: none

Address for correspondence:

Daniela Francescato Veiga

danielafveiga@gmail.com 